\title{
An in vitro assessment of the responses of human dermal fibroblast seeded on 3D
}

\section{printed thermoplastic polyurethane scaffold} 3B Baskılı termoplastik poliüretan iskeleye ekilen insan dermal fibroblast yanıtlarının in vitro değerlendirilmesi Ufkay Karabay 1,2, Selma Aydemir³, Mehtap Yuksel Egrilmez', Basak Baykara³, R. Bugra Husemoglu 'Department of Molecular Medicine, Institute of Health Sciences Dokuz Eylul University, Izmir, Turkey ${ }^{2}$ Department of Pathology Laboratory Techniques, Vocational School of Health Services, Izmir Tinaztepe University, Izmir, Turkey ${ }^{3}$ Department of Histology and Embryology, Faculty of Medicine, Dokuz Eylul University, Izmir, Turkey ${ }^{4}$ Department of Biomechanics, Institute of Health Sciences, Dokuz Eylul University, Izmir, Turkey

\section{Abstract}

Tissue engineering is a multidisciplinary field is an interdisciplinary field for the design of biological substitutes that can improve, restore, and maintain tissue functions. Thermoplastic polyurethanes (TPUs) are linear polymers which are widely used for tissue engineering due to its flexibility in processing methods, biocompatibility and excellent mechanical properties. They are suitable materials for use in three-dimensional (3D) printing. Dermal fibroblasts are mesenchymal cells which play crucial roles in physiological tissue repair. The present study aimed to investigate the viability, proliferation, adhesion, and type IV collagen expression of human dermal fibroblasts (HDFs) seeded on 3D printed TPU scaffolds in vitro. HDFs were seeded on 3D TPU scaffolds or tissue culture polystyrene plates as control and cultured for 1, 3, 7, and 14 days. 3D TPU scaffolds were prepared using a custom made fused deposition modelling printer. The viability and proliferation of cells was analyzed by WST-1 assay on days 1 and 3 . The cell adhesion was evaluated by scanning electron microscopy (SEM) on days 1 and 3 . The cell morphology was examined by hematoxylin and eosin (H\&E) staining. Expression of type IV collagen was analyzed by immunohistochemical (IHC) staining. The viability of HDFs on 3D TPU scaffolds was lower than their control groups on days 1 and 3, slightly higher on day 3. SEM images showed HDF attachment to the 3D TPU scaffold surface with spindle-shaped morphology. H\&E staining demonstrated that HDFs on 3D TPU scaffolds showed smaller morphologies on days 7 and 14 compared to days 1 and 3 . Type IV collagen staining was more intense in HDFs on 3D TPU scaffolds on day 1, 3, and 7 compared to day 14 . In conclusion, our study shows the biocompatibility and the potential applications of 3D printed TPU scaffolds for skin tissue engineering using fibroblasts.

Keywords: TPU, human dermal fibroblast, scaffold

\section{Özet}

Doku mühendisliği, doku fonksiyonlarını iyileştirebilen, restore edebilen ve sürdürebilen biyolojik ikamelerin tasarımı çalışmalarını içeren multidisipliner bir alandır. Termoplastik poliüretanlar (TPU'lar), üretim yöntemlerindeki esneklikleri, biyouyumlulukları ve mükemmel mekanik özellikleri nedeniyle doku mühendisliğinde yaygın olarak kullanılan lineer polimerlerdir. Bu özellikleri ile üç boyutlu (3B) baskıda kullanıma uygun malzemelerdir. Dermal fibroblastlar (HDF), fizyolojik doku onarımında önemli rol oynayan mezenkimal hücrelerdir. Çalışmamızda, in vitro olarak 3B baskılı TPU doku iskelelerine ekilen insan HDF'lerin canlılığı, proliferasyonu, adezyonu ve tip IV kollajen ekspresyonunu araştırmayı amaçladık. HDF'ler, 3B TPU doku iskeleleri ve kontrol olarak doku kültürü polistiren plakaları üzerine ekildi ve 1, 3, 7 ve 14 gün boyunca kültüre edildi. 3B TPU doku iskeleleri, özel yapılmış bir eriyik yığma modelleme (FDM) yazıcısı kullanılarak hazırlandı. Hücrelerin canlılığı ve proliferasyonu, 1. ve 3. günlerde WST-1 testi ile analiz edildi. Hücre adezyonu, 1. ve 3. günlerde taramalı elektron mikroskobu (SEM) ile değerlendirildi. Hücre morfolojisi, hematoksilen ve eozin (H\&E) boyaması ile incelendi. Tip IV kollajen ekspresyonu, immünohistokimyasal (IHC) boyama ile analiz edildi. HDF'lerin 3B TPU doku iskeleleri üzerindeki canlılığı, 1. ve 3. günlerde kontrol gruplarından daha düşük, 3. günde biraz daha yüksekti. H\&E boyaması ile, 3B TPU doku iskelelerindeki HDF'lerin 1. ve 3. günlere kıyasla 7. ve 14. günlerde daha küçük morfolojiler gösterdiği tespit edildi. Tip IV kollajen boyaması, 3B TPU doku iskelelerindeki HDF'lerde 14. güne kıyasla 1., 3. ve 7. günlerde daha yoğundu. Sonuç olarak, çalışmamız, cilt dokusu mühendisliği için 3B baskılı TPU doku iskelelerinin fibroblastlar ile biyouyumluluğunu ve potansiyel uygulamalarını göstermektedir.

Anahtar Kelimeler: TPU, insan dermal fibroblast, doku iskelesi

Correspondence Address : R.Bugra Husemoglu, Department of Biomechanics, Institute of Health Sciences, Dokuz Eylul University, Izmir, Turkey bugrahusem@gmail.com
ORCID ID of the author: U.K 0000-0001-8608-1865, S.A 0000-0003-1263-9998, M.Y.E 0000-00023570-1865, B.B 0000-0002-4178-2235, R.B.H 0000-0003-1979-160X

Please cite this article in press at: Karabay U., Aydemir S., Egrilmez M.Y., Baykara B., Husemoglu R. B., An in vitro assessment of the responses of human dermal fibroblast seeded on 3D printed thermoplastic polyurethane scaff, Journal of Medical Innovation and Technology, 2021; 3 (2): 23-27 doi 10.51934/jomit.1049419 


\section{Introduction}

Dermal fibroblasts are cells of mesenchymal origin that play a key role in skin homestasis. They secrete extracellular matrix (ECM) and provide a physical support for other cells to perform their biological functions (1). They are critical in supporting physiological tissue repair (2). Impaired wound healing is commonly associated with comorbidity characteristics, such as diabetes, obesity and autoimmune diseases (3). One of the most promising wound healing approaches involves cell seeded-scaffolds. A scaffold is typically used to provide structural support for cell attachment, differentiation, proliferation and migration (4). Three-dimensional (3D) printed constructs are suitable candidates to provide a biomimetic structural environment that facilitates accelerated wound healing (5).

Thermoplastic polyurethanes (TPUs) are linear segmented block polymers containing hard segments and soft segments (6). They are characterized by high biocompatibility, biodegradability, moderate bending strength and resistance to abrasion (7). Properly designed TPUs are suitable materials for use in 3D printing by the fused deposition modeling (FDM) [8].

In an engineered in vitro model, the scaffold should be designed to replicate in vitro the architecture of the native tissue. Cell infiltration and inflammatory response are essential for sufficient remodeling and successful tissue regeneration of an implanted degradable material. Dermal fibroblasts are commonly used in 3D printed tissue scaffolds of different biomaterials for tissue engineering applications. The constantly growing areas of application make the optimization of TPU materials indispensable.

In this study, we aimed to investigate the viability, proliferation, adhesion, and type IV collagen expression of human dermal fibroblasts (HDFs) seeded on 3D printed TPU scaffolds in vitro.

\section{Materials and Methods}

\section{Cell culture}

Adult HDFs were obtained from ATTC (USA). They were cultured using fibroblast growth medium at $37^{\circ} \mathrm{C}$ in a humidified atmosphere containing $5 \% \mathrm{CO} 2$. When the cells were $90 \%$ confluent, they were trypsinized and seeded on 3D printed TPU scaffolds. Cells were used between 5-6 passages.
Fabrication of 3D printed TPU scaffolds

Scaffolds template $(\varnothing=4 \mathrm{~mm}$, thickness $=2 \mathrm{~mm})$ were designed using SolidWorks 2019 software and subsequently filled and sliced using and Ultimaker Cura 4.11 software to obtain cylindrical STL models. Briefly, clump generator software was used to create squared pores into a 3D object in a "stl" पle format. 3D-printed scaffolds were prepared from TPU (eSun Filament, Shenzhen, China). The 3D printer was a customized system working by the mechanism of FDM. Printing was performed by the custom made FDM printer, using a nozzle diameter of $0.4 \mathrm{~mm}$, a layer thickness of $0.2 \mathrm{~mm}$, a nozzle temperature of $240^{\circ} \mathrm{C}$ TPU, and a printing bed temperature of $40^{\circ} \mathrm{C}$. All scaffolds had a thickness of $2 \mathrm{~mm}$. Both layers were printed with three perimeter lines and rectilinear filling under an angle of $0-90^{\circ}$, applying a flow rate of $100 \%$. Printing speed was set to be $60 \mathrm{~mm} / \mathrm{s}$ for all materials. Prior to biological evaluations, printed scaffolds were sterilized by ethylene oxide.

\section{Cell Seeding on 3D printed TPU scaffolds}

Sterile 3D TPU scaffolds were immersed in fibroblast growth medium in the 96-well plate. Then, they were incubated overnight in a humidified incubator at $37^{\circ} \mathrm{C}$ with $5 \%$ CO2 prior to cell seeding. Suspension of HDFs in fibroblast growth medium were seeded on the 3D printed TPU scaffolds at $4 \times 104$ cells per well and incubated for $4 \mathrm{~h}$ to allow cell attachment. Each well was completed to $150 \mu \mathrm{L}$ complete medium in total volume. In order to eliminate the cells that do not attach to scaffolds, 16-24 hours after seeding the scaffolds were placed in another 96-well plate. HDFs with equivalent numbers were also seeded on tissue culture polystyrene plates without scaffolds as a control group. 3D TPU scaffolds were cultured for 1 and 3 days.

Measurement of viability and proliferation on 3D printed TPU Scaffolds

The viability of HDFs on 3D TPU scaffolds was determined by ready-to-use colorimetric WST-1 assay (Biovision, USA). The assay is based upon the cleavage of the tetrazolium salt WST-1 to formazan by cellular mitochondrial dehydrogenases. The amount of formazan dye produced was measured at $450 \mathrm{~nm}$ by using a microplate reader (Biotek Synergy HTX, USA). The cell viability of the control group was accepted as $100 \%$ and the relative cell viability was calculated respect to this value.

\section{Scanning electron microscopy}

The adhesion and the morphology of HDFs on 3D TPU scaffolds were examined by scanning electron microscopy 
(SEM). The cells were cultured for 1 and 3 days on 3D TPU scaffolds. Then, the cell-scaffolds constructs were transferred to the 24 -well plate, fixed with $4 \%$ paraformaldehyde and immersed in a graded series of ethanol $(60 \%, 70 \%, 80 \%$ and $99 \% \mathrm{v} / \mathrm{v}$ ). The scaffolds were wrapped in aluminum foil and dried in the desiccator for 2 days (8). The scaffolds placed on the platform were plated with $5 \mathrm{~nm}$ gold for 20 minutes by the Q150R S (Quorum) instrument. Copper banding was then applied to the platform to eliminate charging effect. Images were taken by ZEISS Sigma 500 VP FE-SEM.

\section{Histological staining}

HDFs on 3D TPU scaffolds were cultured for 1, 3, 7, and 14 days. Cell-scaffold constructs were removed, washed three times in PBS and fixed in $4 \%$ paraformaldehyde at $4^{\circ} \mathrm{C}$ for $24 \mathrm{~h}$. This was followed by a tissue processing procedure, embedded in paraffin and cut into $5 \mu \mathrm{m}$ thick sections. The sections were then stained with hematoxylin \& eosin (H\&E) and were examined under light microscope (Olympus, BX51 microscope) (9). In immunohistochemical (IHC) evaluation, $5 \mu \mathrm{m}$ thick sections were treated with type IV collagen antibody (bs 10423R, Bioss) and incubated at $4^{\circ} \mathrm{C}$ for overnight. Antigenic sites were visualized by diaminobenzidine solution and counterstained with hematoxylin. The images were taken with a light microscope (Olympus BX51 microscope) with X20 magnification $(10,11)$.

\section{Statistical analysis}

Statistical analyses were performed using SPSS 24 software program. The results were expressed as mean \pm SD. Two groups were compared using Mann Whitney U test. A value of $p<0.05$ was considered significant.

\section{Results}

The viability and proliferation of HDFs on 3D TPU Scaffolds

The number of HDFs on the 3D TPU scaffolds showed a decrease on day 1 compared to control cells on tissue culture plastic plates without scaffolds $(p<0.05)$ (Figure $1 A$ ). On day 3, the number of HDFs on the 3D TPU scaffolds were still lower than the control cells. However, the number of cells showed a tendency to increase on day 3 showing cell poliferation $(p<0.05)$ (Figure 1B).

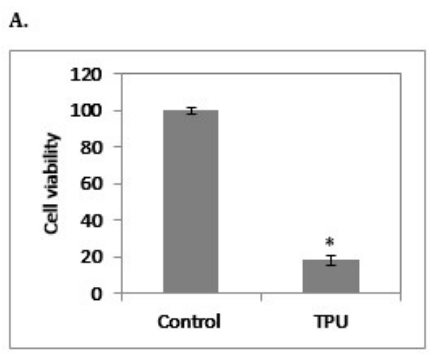

B.

Figure 1. The viability and proliferation of HDFs on 3D TPU scaffolds on day $1(A)$ and day $3(B)$. * $\mathrm{p} \square 0.05$ in comparison with control.

\section{The morphology of HDFs on 3D TPU scaffolds}

We vizualized whether HDFs were capable of adhering to 3D TPU scaffolds via SEM. HDFs adhered to the surfaces of 3D TPU scaffolds, filled the interfiber gaps and maintained their spindle-shaped morphology on days 1 and 3 . The cell-cell and cell-scaffold interactions increased on day 3 compared to day 1 showing the biocompatibility of the 3D TPU scaffolds (Figure 2).

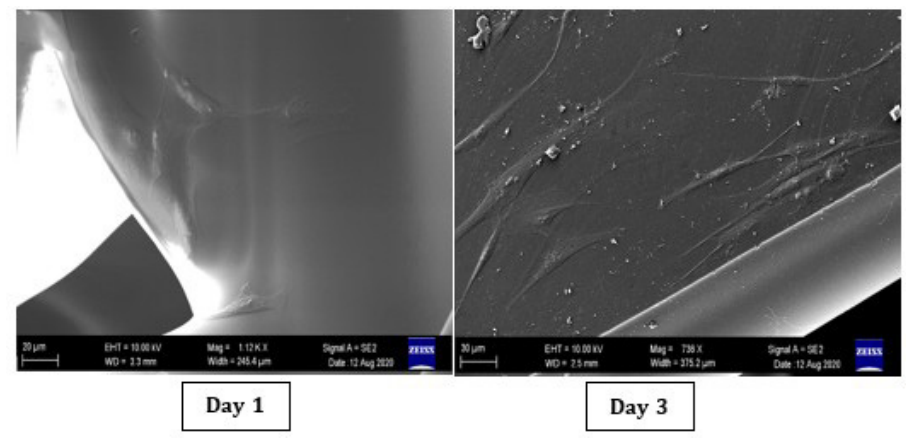

Figure 2. SEM images of HDFs on 3D TPU scaffolds on days 1 and 3.

Histological analysis

H\&E staining demonstrated that HDFs attached to 3D TPU scaffolds in on days $1,3,7$, and 14 . We found that HDFs on 3D TPU scaffolds showed smaller morphologies on days 7 and 14 compared to days 1 and 3 . The adherence and proliferation of HDFs seeded on 3D TPU scaffolds on day 14 were lower than days 1, 3, and 7 (Figure 3).

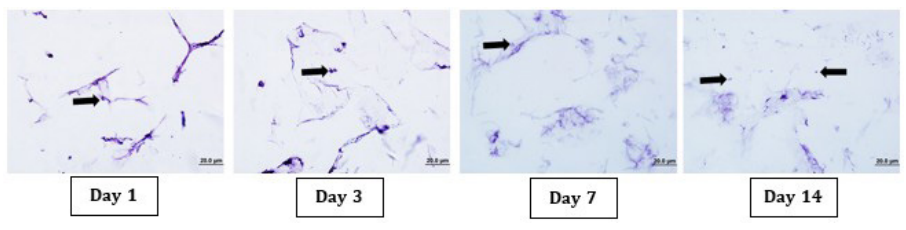

Figure 3. H\&E staining in HDFs seeded on 3D TPU scaffolds on days $1,3,7$, and 14 . Black arrows indicate HDFs. 
Type IV collagen expression was observed in HDFs on 3D TPU scaffolds on days 1, 3, 7, and 14. Type IV collagen staining in HDFs on 3D TPU scaffolds was moderate and similar on days 1, 3, and 7. However, type IV collagen staining was less intense on day 14 compared to other days (Figure 4).

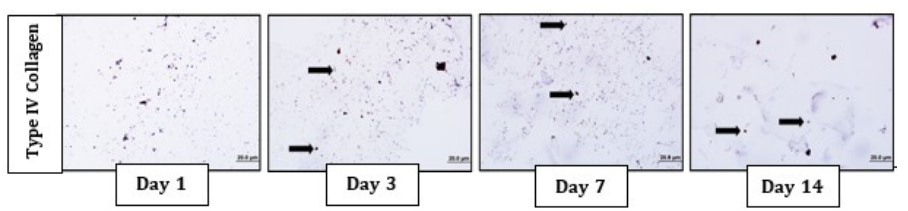

Figure 4. Type IV collagen staining in HDFs seeded on 3D printed TPU scaffolds on days 1, 3, 7, and 14. Black arrows indicate stained HDFs.

\section{Discussion}

The aim of this study was to investigate the biocompatibility of 3D printed TPU scaffolds by using HDFs in vitro. The viability, adhesion, proliferation, and type IV collagen expression of HDFs seeded on the 3D TPU scaffolds were analyzed.

3D printing is the state-of-the-art technology for tissue engineering applications. The development of 3D printed polymer scaffolds provides control of the architecture and allowing to study the effects of the geometry in cellular responses (13). TPU is a linear polymer consists of polar hard and nonpolar soft segments. They are mainly used because of its biocompatibility, high fracture strain, adequate tensile strength and abrasion resistances (14).

Dermal fibroblasts are instrumental in the physiological tissue repair. SEM images showed that HDFs adhered to the surfaces of 3D printed TPU scaffolds and showed spindle-shaped morphology on days 1 and 3 . This result shows the biocompatibility of the 3D TPU scaffolds in terms of adherence in HDFs. The number of HDFs on the 3D TPU scaffolds showed a decrease on days 1 and 3 compared to control group. However, the cell number tended to increase on day 3 , resulting a slightly higher cell viability compared to day 1. 3D TPU scaffolds with soft properties were used in this study. Mi et al showed that the number of $3 \mathrm{~T} 3$ fibroblasts on TPU scaffolds with soft properties were lower than the number of cells on TPU scaffolds with hard properties (15). Another study also reported that the number of human monocytes on soft TPU scaffolds were lower than the number of cells on hard TPU scaffolds (16). Our low cell viability results for HDFs on soft TPU scaffolds are similar with these previous studies.

H\&E staining showed that HDFs attached to 3D TPU scaffolds on days $1,3,7$, and 14 . They were found to be in smaller morphologies on days 7 and14 compared to days 1 and 3 .
The adherence and proliferation of HDFs seeded on 3D TPU scaffolds on day 14 were lower than days 1, 3, and 7. Type IV collagen is primarily found in the skin within the basement membrane zone (17). Olsen et al showed the expression of type IV collagen in HDFs (18). Betz et al emphasized the importance of type IV collagen expression in wound healing (19). In our study, type IV collagen expression was observed in HDFs on 3D printed TPU scaffolds on days 1, 3, 7, and 14. Type IV collagen staining in HDFs on 3D TPU scaffolds was moderate and similar on days 1, 3, and 7. However, type IV collagen staining was less intense on day 14 compared to other days. These histological observations demonstrated the presence of HDFs on 3D TPU scaffolds and the attachment of HDFs to these scaffolds.

\section{Conclusion}

Our present study assessed the responses of HDFs seeded on 3D printed TPU scaffolds in vitro. Overall, our results show the biocompatibility and the potential applications of 3D printed TPU scaffolds for skin tissue engineering using fibroblasts. 


\section{References}

1. Haniffa MA, Wang X-N, Holtick U, Rae M, Isaacs JD, Dickinson AM, Hilkens CMU, Collin MP. Adult human fibroblasts are potent immunoregulatory cells and functionally equivalent to mesenchymal stem cells. J Immunol 2007;179:1595-1604.

2. Forrest, L. Current concepts in soft connective tissue wound healing. Br J Surg 1985;70:133-40.

3. Negut I, Dorcioman G, Grumezescu V. Scaffolds for wound healing applications. Polymers (Basel), 2020;12: 2010.

4. Behere I, Ingavle G. In vitro and in vivo advancement of multifunctional electrospun nanofiber scaffolds in wound healing applications: Innovative nanofiber designs, stem cell approaches, and future perspectives. J Biomed Mater Res A 2022;110:443-61.

5. Richards DJ, Tan Y, Jia J, Yao H, Mei Y. 3D Printing for tissue engineering. Isr J Chem. 2013;53:805-14.

6. Harynska A, Kucinska-Lipka J, Sulowska A, Gubanska I, Kostrzewa M, Janik H. Medical-Grade PCL based polyurethane system for FDM 3D Printing-Characterization and Fabrication. Materials (Basel). 2019 Mar 16;12:887.

7. Joseph J, Patel RM, Wenham A, Smith JR. Biomedical applications of polyurethane materials and coatings. Trans Inst Met Finish. 2018;96:121-29.

8. Xiao J, Gao Y. The manufacture of 3D printing of medical grade TPU. Prog Addit Manuf 2017; 2: 117-23.

9. Farrugia BL, Brown TD, Upton Z, Hutmacher DW, Dalton PD, Dargaville TR. Dermal fibroblast infiltration of poly $(\varepsilon-$ caprolactone) scaffolds fabricated by melt electrospinning in a direct writing mode. Biofabrication. 2013;5: 025001.

10. Huerta RR, Silva E, Ekaette I, El-Bialy T, Saldaña MDA. High-Intensity ultrasound-assisted formation of cellulose nanofiber scaffold with low and high lignin content and their cytocompatibility with gingival fibroblast cells. Ultrason Sonochem 2020;64:104759.

11. Chen WC, Wei YH, Chu IM, Yao CL. Effect of chondroitin sulphate $C$ on the in vitro and in vivo chondrogenesis of mesenchymal stem cells in crosslinked type II collagen scaffolds. J Tissue Eng Regen Med 2013;7:665-72.
12. Griffin MF, Naderi N, Kalaskar DM, Seifalian AM, Butler PE. Argon plasma surface modification promotes the therapeutic angiogenesis and tissue formation of tissueengineered scaffolds in vivo by adipose-derived stem cells. Stem Cell Res Ther 2019;10:1-14.

13. Hollister SJ. Porous Scaffold Design for Tissue Engineering. Nature Materials 2005;4:518-24.

14. Tatai L, Moore TG, Adhikari R, Malherbe F, Jayasekara R, Griffiths I, Gunatillake PA. Thermoplastic biodegradable polyurethanes: The effect of chain extender structure on properties and in-vitro degradation. Biomaterials 2007;28:5407-17.

15. Mi HY, Jing X, Salick MR, Cordie TM, Peng XF, Turng LSh. Properties and fibroblast cellular response of soft and hard thermoplastic polyurethane electrospun nanofibrous scaffolds. J Biomed Mater Res B Appl Biomater . 2015;103:960-70.

16. Woitschach F, Kloss M, Schlodder K, Borck A, Grabow N, Reisinger EC, Sombetzki M. In vitro study of the interaction of innate immune cells with liquid silicone rubber coated with zwitterionic methyl methacrylate and thermoplastic polyurethanes. Materials 2021;14:5972.

17. Hasegawa H, Naito I, Nakano K, Momota R, Nishida K, Taguchi T, et al. The distributions of type IV collagen alpha chains in basement membranes of human epidermis and skin appendages. Arch Histol Cytol 2007;70:255-65.

18. Olsen DR, Peltonen J, Jaakkola S, Chu ML, Uitto J. Collagen gene expression by cultured human skin fibroblasts. Abundant steady-state levels of type VI procollagen messenger RNAs. J Clin Invest 1989;83(3): 791-5.

19. Betz P, Nerlich A, Wilske J, Tübel J, Wiest I, Penning R, et al. The time-dependent rearrangement of the epithelial basement membrane in human skin wounds-immunohistochemical localization of Collagen IV and VII. Int J Legal Med 1992;105:93-7. 